\title{
Land use changes and groundwater quality in Florida
}

\author{
Can Denizman ${ }^{1} \mathbb{D}$
}

Received: 12 September 2017 / Accepted: 31 July 2018 / Published online: 6 August 2018

(c) The Author(s) 2018

\begin{abstract}
Land use changes around 26 karstic cave-spring systems in Florida were evaluated using geographic information system. Located in the unconfined or semiconfined zones of the Floridan aquifer, some of the cave-spring systems are directly connected to the surficial land use processes by sinking streams, whereas others receiving diffuse recharge are still vulnerable to contamination due to a thin sandy cover overlying the aquifer. Comparison of nitrate-producing land use practices between 2004 and 2013-2014 shows increasing risks of groundwater contamination in the Floridan aquifer. Proliferation of septic systems and wastewater treatment sites due to growing residential areas, increased use of fertilizers for farming and landscaping stand out as major causes of nitrate overload in the both surface and groundwater.
\end{abstract}

Keywords Nitrate $\cdot$ Karst $\cdot$ Floridan aquifer $\cdot$ GIS · Groundwater contamination

\section{Introduction}

As the largest liquid freshwater reservoir of our planet, groundwater has been under stress in terms of both quantity and quality. Overpumping to meet the demands of the rapidly growing population in urban areas, coupled with frequent droughts in many parts of the world, has put a substantial stress on groundwater reservoirs. Unsustainable exploitation of aquifers resulted in groundwater mining and seawater intrusion in coastal aquifers. Moreover, groundwater quality has been profoundly impaired not only by point contamination sources such as industrial or municipal waste repositories, but also by nonpoint contamination events such as widespread application of fertilizers and a wide range of chemicals for increased agricultural production (Ki et al. 2015; Wongsabit et al. 2015; Kihumbal et al. 2016; Elisante and Muzuka 2017).

Groundwater contamination becomes much more severe and difficult to deal with in karst aquifers due to their unique groundwater storage and flow characteristics. First, karst aquifers are directly connected to surficial process via dolines, swallets, and disappearing streams. Second, most groundwater flow takes place in enlarged cavities and

Can Denizman

cdenizma@valdosta.edu

1 Department of Physics, Astronomy, and Geosciences, Valdosta State University, Valdosta, GA 31698, USA conduits with no natural filtration and attenuation of the pollutants. Third, groundwater flow occurs in a dual-porosity medium, i.e., both in matrix and conduit porosity, with drastically different groundwater flow path lengths and residence times. Fourth, contamination plumes may travel much faster than conventional aquifers (COST Action 2004).

In addition to these features of vulnerability, groundwater flow and contaminant transport modeling in karst aquifers require unique approaches. Their anisotropic and heterogeneous structures do not allow them to be adequately characterized by conventional Darcian groundwater flow models (Hartmann et al. 2014).

These unique properties of karst aquifers and the their subsequent vulnerability to groundwater contamination caused by land use practices have been widely addressed in scientific literature (e.g., Lan et al. 2015; Guo et al. 2006; Hasenmuller et al. 2006; Jiang and Yan 2010). A typical case of rapid groundwater flow in a karst aquifer and contamination in municipal wells is reported by Worthington et al. (2002). They discuss the widespread distribution of pathogens due to rapid groundwater flow without attenuation or filtering within the enlarged conduits of the aquifer. In a similar case, Quinlan (1983) discusses rapid and extensive distribution of contamination within the karstic aquifer of the Sinkhole Plain in Kentucky. In addition to a great deal of research on karst groundwater contamination, many studies focused on groundwater protection and management of karst aquifers (Boyer and Pasquarell 1999; Plagnes and 
Bakalowicz 2001; Boyer 2005; Jimenez-Madrid et al. 2012; Eftimi and Zojer 2015; Vallejos et al. 2015).

As one of the major karst aquifers in the world, the Floridan aquifer has been under substantial stress that threatens to impair the groundwater quality and quantity mainly due the population growth from about two millions in 1940s to more than 21 millions (http://worldpopulationreview.com/states/ florida-population/). An increasingly common cause of surface and groundwater quality impairment in Florida has been the documented steady increase of nitrate over the past several decades (Jones et al. 1996; Champion and DeWitt 2000; Hornsby et al. 2004). Copeland et al. (2011) show 19-fold increase in nitrate concentrations in 13 selected first-magnitude springs between the 1970s and 2000. A plant nutrient along with phosphorus, carbon, potassium, and iron, nitrate is essential for a healthy ecosystem. However, anthropogenic nutrient overload results in excessive growth of algae, and consequently in eutrophication, a growing problem in Florida's surface and spring waters (Edwards et al. 2006; Heffernon et al. 2010; Fulton et al. 2015; Lapointe et al. 2015).

Many studies have attempted to identify the sources and the land use practices that cause nutrient overload in Florida's springs and lakes. In general, most of them state that common sources of nitrate include fertilizers and organic waste that originate from areas of livestock, septic tanks, and wastewater treatment plants. For example, in their study on the nonpoint source pollution in Lower St. Marks-Wakulla River Watershed in Florida, Chelette et al. (2002) cite on-site disposal systems such as septic tanks and cesspits, livestock and commercial fertilizers to explain a threefold increase in total nitrate discharged from the Wakulla springs in the last 25 years. In a later study of the Wakulla Springs area, Eller and Katz (2014) report that septic tanks contribute more nitrogen to groundwater, comprising $51 \%$ of the total nitrogen loads. They cite farm fertilizer as the leading source of nitrogen in areas where the Floridan aquifer is confined. Similarly, in their study on the nitrate concentration within the Suwannee River Water Management District, Upchurch et al. (2007) cite two major sources of nitrogen: (1) application of fertilizers to cropland, i.e., land use practices such as row crops, pastures, and groves, and turf such as lawns and golf courses, and (2) animal wastes, including wastes from feedlots, septic tanks, wastewater treatment, and other sources.

Notwithstanding the preponderance of studies on Florida's water quality, mostly reporting an alarmingly increasing trend of nutrient overload due to certain land use practices, there has not been much attempt to determine the land use changes over time. Overall, a statewide urbanization due to population growth can be readily observed, but there is not much information about the extent of nutrient-loading land use changes around cave-spring systems. In this study, land use changes around major cave-spring systems between 2004 and 2013-2014 are examined as potential causes of nutrient overload in the Floridan aquifer groundwater.

\section{Study area and hydrogeologic setting}

The study area covers 26 cave-spring systems in Florida (Fig. 1). These systems represent well-developed sinkhole-cave-spring continuum within the karstic Floridan aquifer.

The Florida carbonate platform is composed of a thick sequence of variably permeable limestone and dolostone, deposited in a stable passive continental margin through most of the Paleogene. Extensively karstified carbonates with high primary porosity give rise to the Floridan aquifer, a prolific aquifer that enjoys abundant recharge from the subtropical rainfall pattern of the area. In much of Florida and Georgia, the Floridan aquifer is confined by a varying thickness of siliciclastic material (Miller 1986). Generally, the confinement provides hydrologic decoupling of the aquifer from surficial contamination sources. Groundwater recharge in the confined area occurs through collapse and subsidence dolines that act as karstic windows to the aquifer by breaching the confining layer.

Impermeable siliciclastic sediments that comprise the confining unit deposits have been entirely or partially eroded along the Suwannee River, resulting in unconfined conditions where the aquifer is directly impacted by surficial process (Miller 1997; Williams and Kuniansky 2016) (Fig. 2). Here, recharge to the Floridan aquifer takes place either by diffuse recharge through a thin sand layer or by point recharge where allogenic streams encounter the carbonate rocks (Upchurch and Lawrence 1984). Unlike many other karst aquifers, the Floridan aquifer has significant primary (matrix/intergranular) and the secondary (conduit) porosities. This dual porosity brings about two different groundwater flow regimes: Darcian flow within the intergranular medium and turbulent and non-Darcian flow within the dissolutional conduits.

\section{Data and methods}

This study is based on geographic information system (GIS) analyses of the spatial data. GIS has been widely applied to groundwater contamination studies to determine potential 


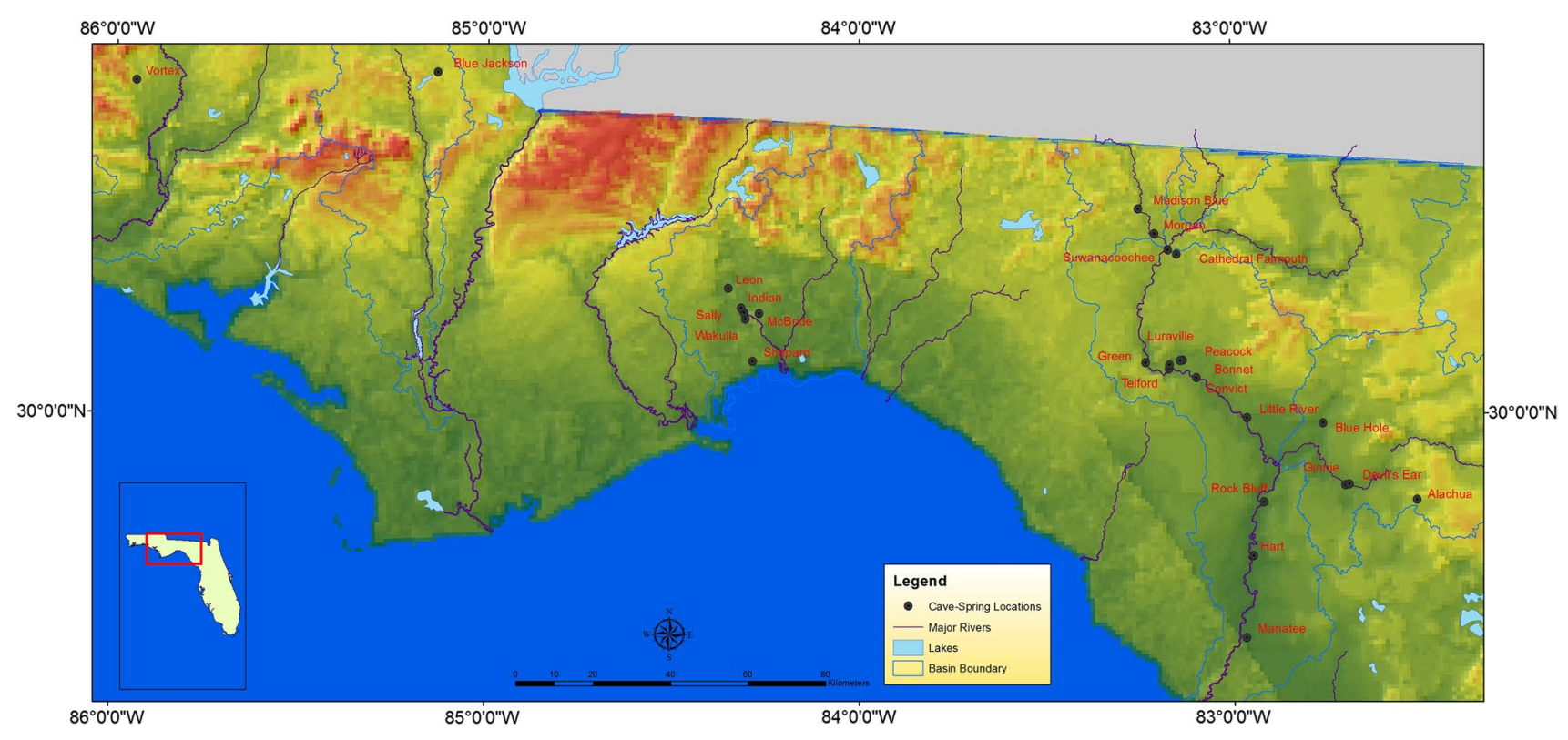

Fig. 1 Cave/spring locations

Fig. 2 Cave/spring locations and the Floridan aquifer confinement

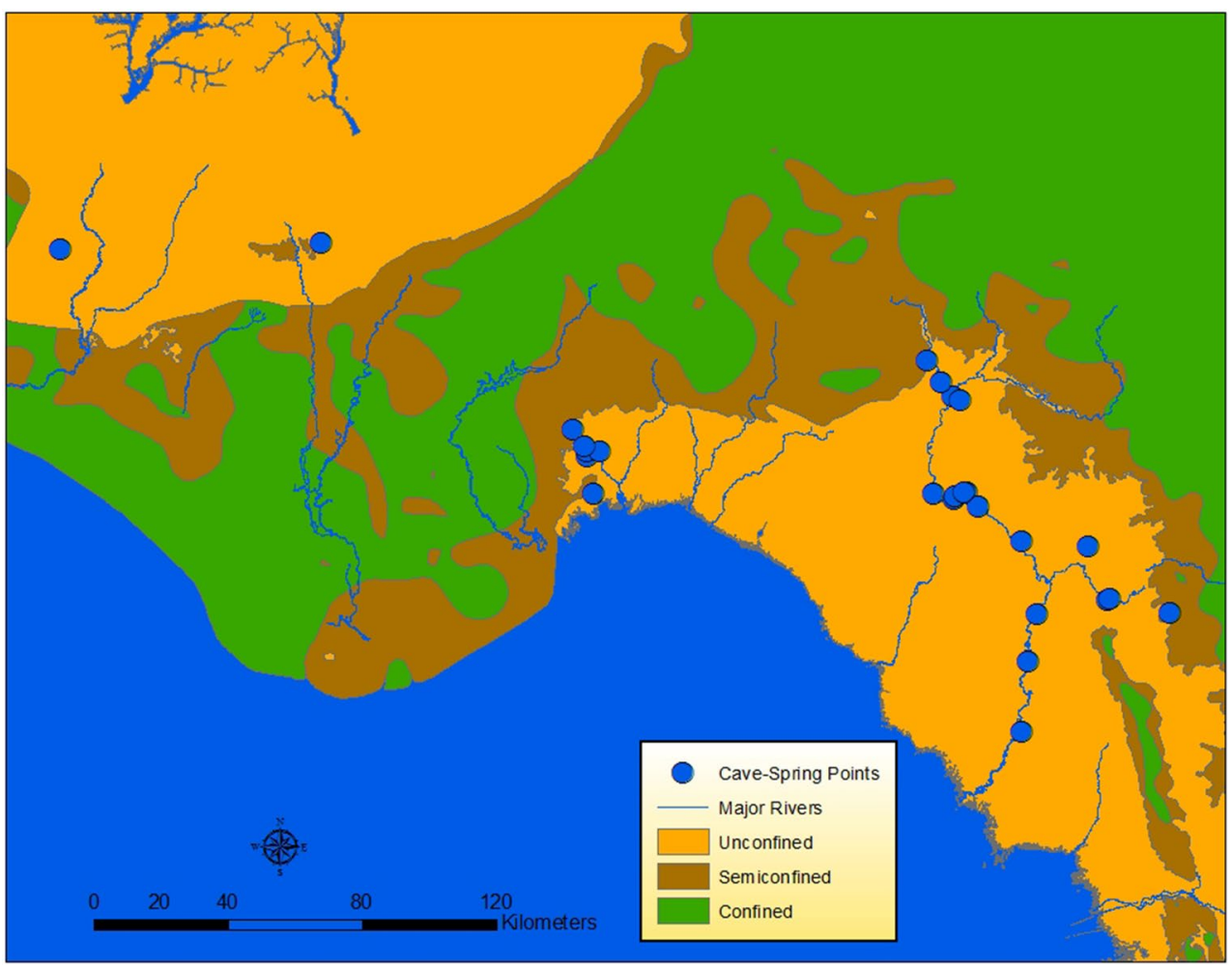


zones of vulnerability to surficial contamination (Stark et al. 1999; Davis et al. 2002; Capri et al. 2009; Sener and Davraz 2013; Jasrotia and Kumar 2014; Edet 2014; Tokatli 2014; Barroso et al. 2015; Bozdag 2015), or to create interactive karst databases (see Gao and Zhou (2008) for a review of GIS applications to karst). Regarding the land use impact on groundwater quality, Khan et al. $(2011,2017)$ discuss two case studies of GIS application to calculate groundwater quality index and to prepare a map of groundwater sustainability in terms of water quality.

In Florida, GIS has been widely used especially by the State's Water Management Districts and the Florida Geological Survey. Among many publications and maps, a comprehensive GIS model developed by Arthur et al. (2005) can be named as a significant contribution to the assessment of the aquifer's vulnerability to contamination.

The method applied in this study involves a series of GIS operations to determine land use changes within $10 \mathrm{~km}$ of selected cave-spring systems between 2004 and 2013-2014 using ESRI's ArcGIS 10.2. The data used in this study are as follows:

Caves: The centerlines of cave-springs systems, located within the unconfined or semiconfined zones of the Floridan aquifer, were digitized by the author. An example of these data (Wakulla Cave/Spring System) is shown in Fig. 3. The data are in polyline and in point shapefile format.

Land use: 2004 and 2013/2014 Land Use data were obtained from Suwannee River and Northwest Florida Water Management Districts. They are created by the Florida Department of Environmental Protection's Bureau of Watershed Restoration, on Digital Ortho Quarter Quad Aerial Imagery program using color infrared and true color photography. They are in polygon format.

DEP cleanup sites: They are created by Florida Department of Environmental Protection (DEP) in point shapefile format.

The GIS analysis performed in this study consists of buffer and clip operations. In order to observe land use

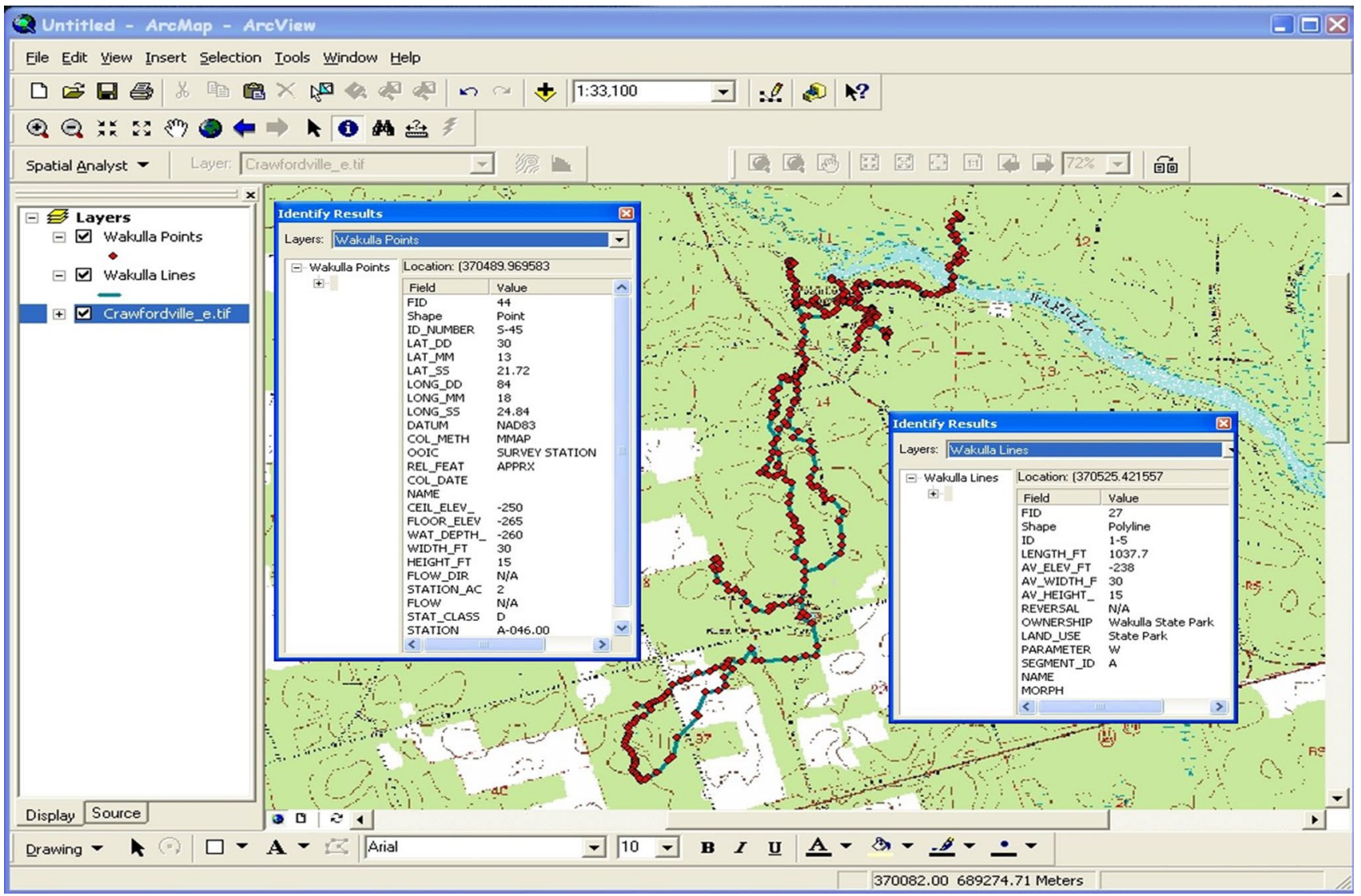

Fig. 3 Wakulla cave passage centerline 
Fig. 4 Land use within $10 \mathrm{~km}$ of Madison Blue cave passage centerline (2004)

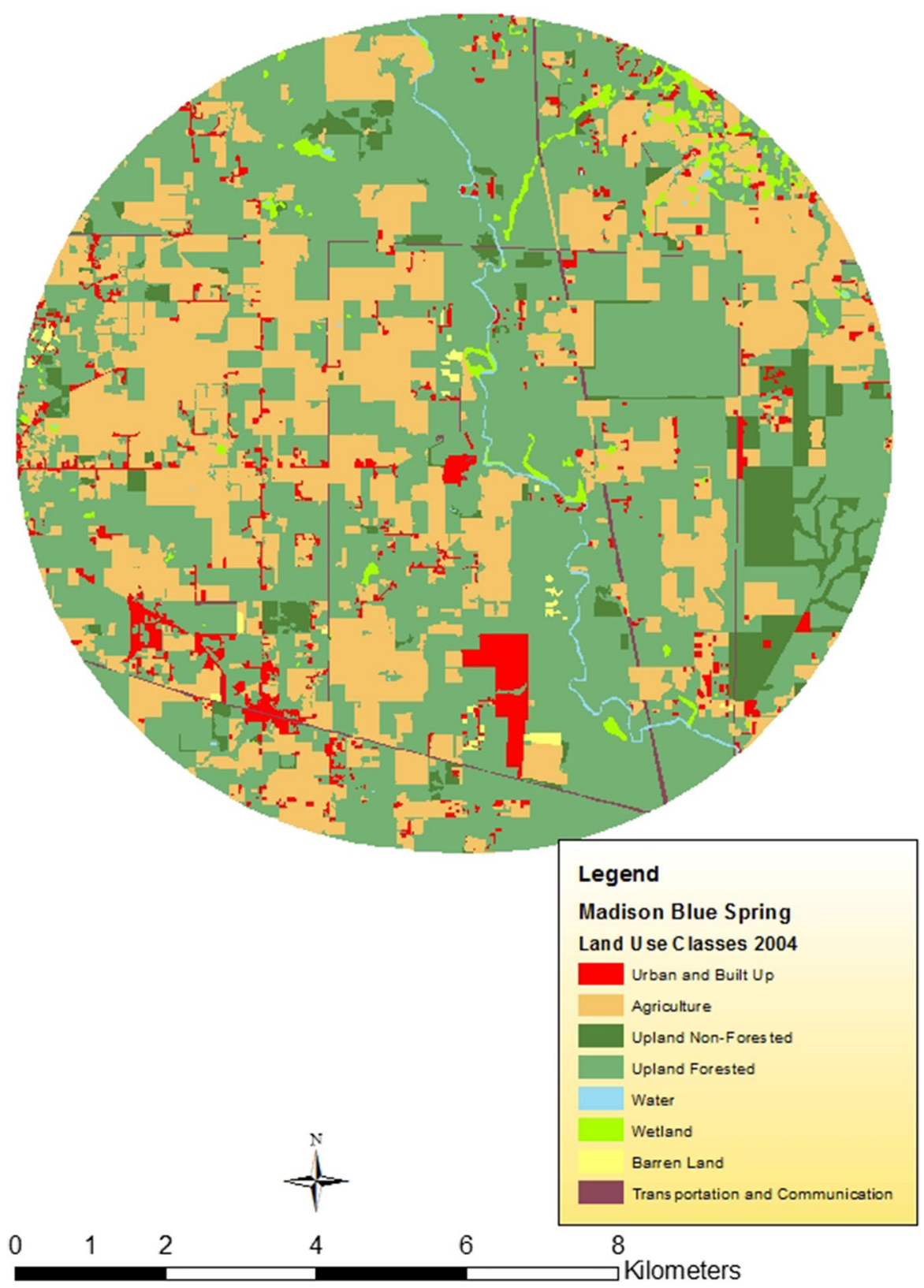

changes around the cave systems, land use layers of 2004 and 2013-2014 were clipped by 10-km buffers around cave passages, and percentages of selected categories were compared (see Figs. 4 and 5 for land use clipped around Madison Blue cave/spring system). GIS was also used to determine the areal percentages of septic systems around the caves and to find the number of hazardous waste sites that are closest to each cave.

\section{Results and discussion}

As discussed above, elevated nitrate concentrations in Florida's springs and streams have been widely reported in scientific literature. In this study, available historic nitrate data obtained from the Suwannee River Water Managements District are presented in Fig. 6. Data are available for only 
Fig. 5 Land use within $10 \mathrm{~km}$ of Madison Blue cave passage centerline (2013/14)

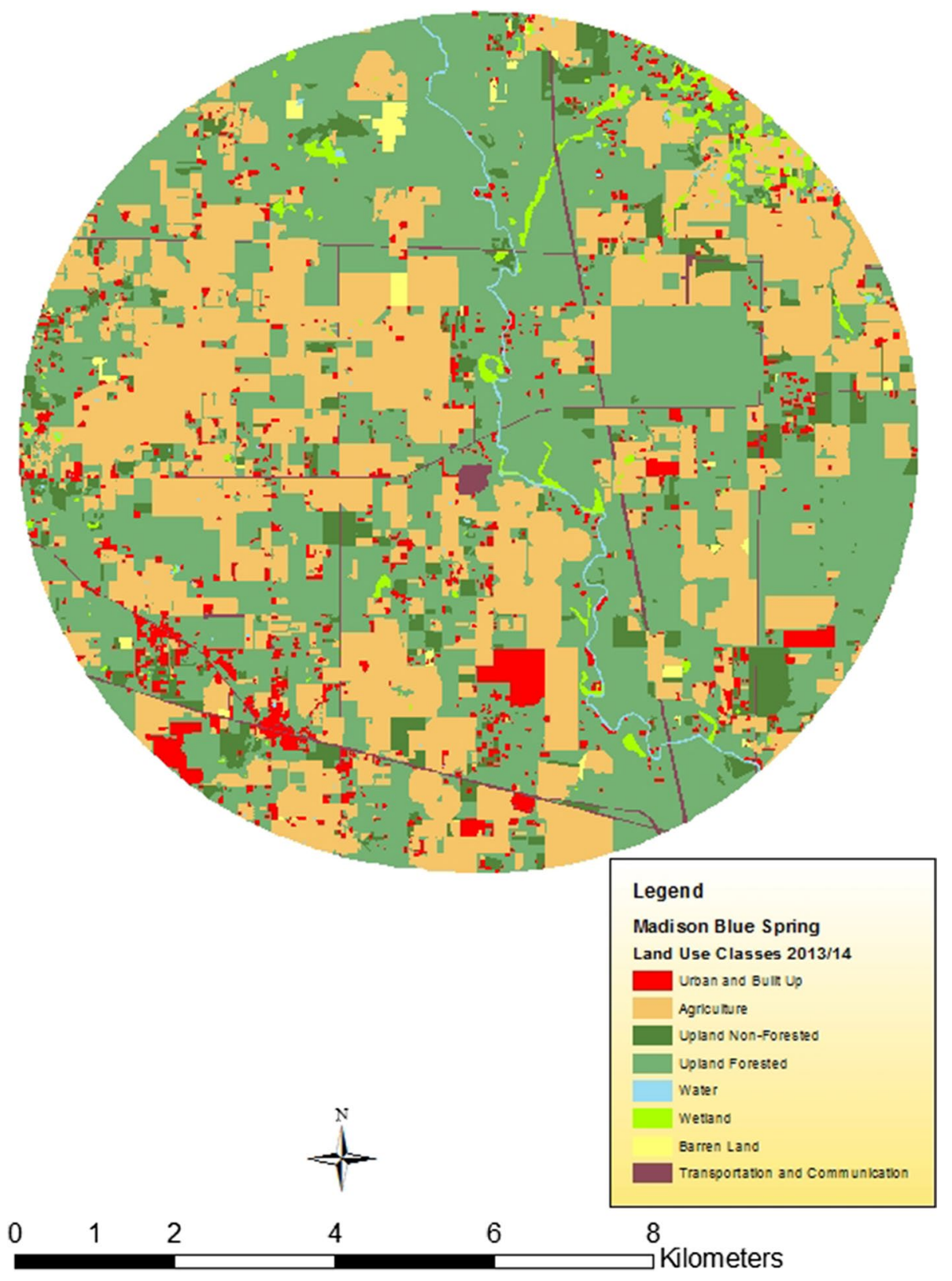

nine of the cave/spring systems selected for this study. There are increasing trends for all but Falmouth and Little River springs between early 1990s and 2013. Total nitrate concentrations are generally below $2.5 \mathrm{mg} / \mathrm{l}$ except for Convict springs with higher than $10 \mathrm{mg} / \mathrm{l}$ values repeatedly detected after late 2009.

A review of all the potentially nutrient-loading land use practices (Table 1) shows increasing trends for 14 cave-spring systems (Bonnet, Cathedral-Falmouth, Convict,
Devil's Ear, Green, Hart, Little River, Luraville, Madison Blue, Morgan, Peacock, Rock Bluff, Suwanacoochee, and Telford) (Table 2, Fig. 7).

Individual analysis of these land use practices reveals similar trends. Residential areas increase around all but two caves (Table 3, Fig. 8). Especially around Ginnie springs, there has been substantial amount of development. The cluster of Telford, Convict, Little River, and Blue Hole stands 


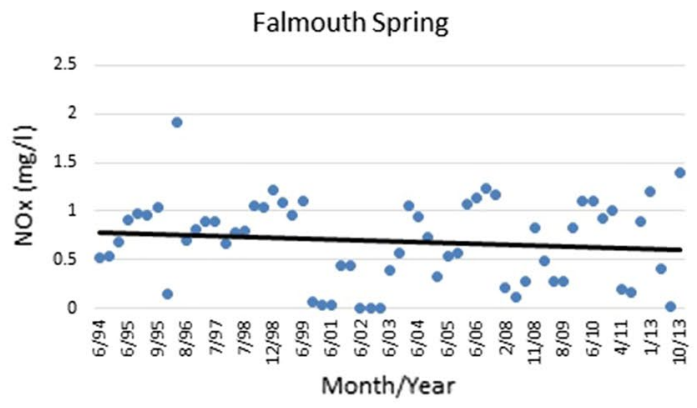

Ginnie Springs

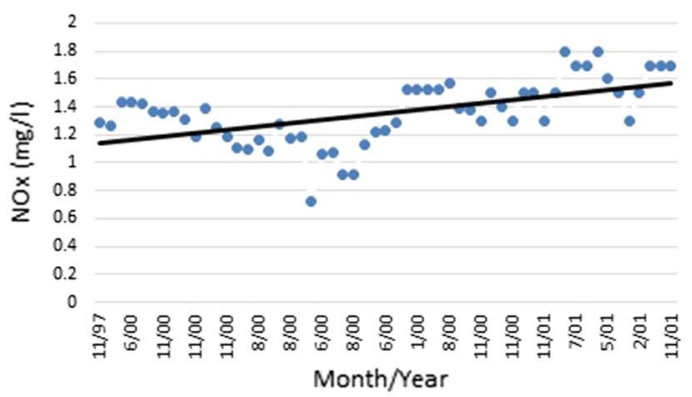

Little River Spring

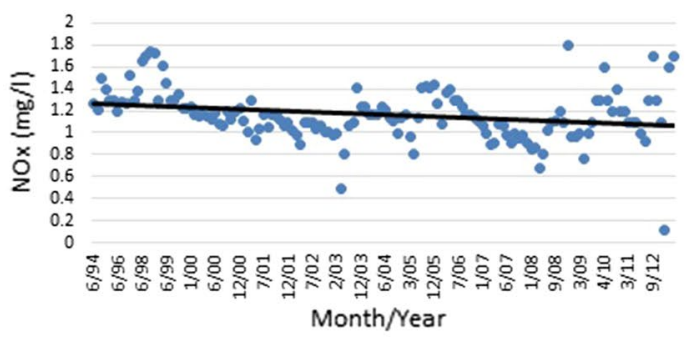

Manatee Spring

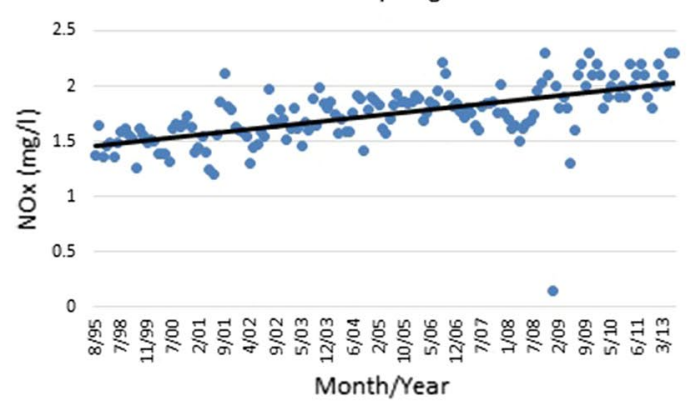

Convict Spring

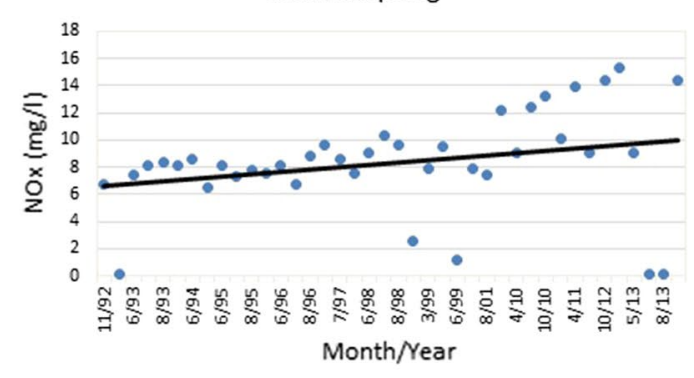

Hart Spring

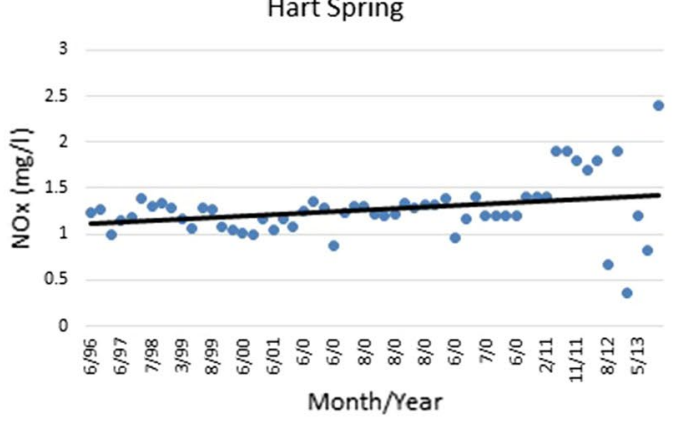

Madison Blue Spring

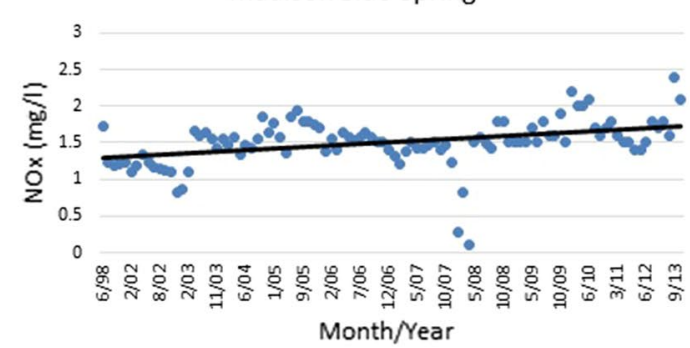

Rock Bluff Spring

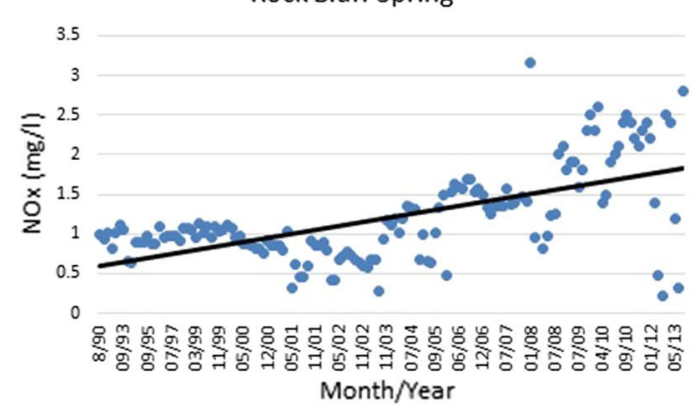

Telford Spring

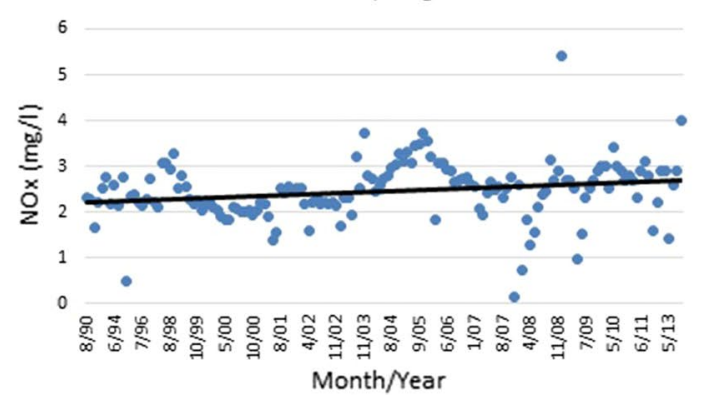

Fig. 6 Total nitrate concentration changes in time for selected springs 
Table 1 Land use categories

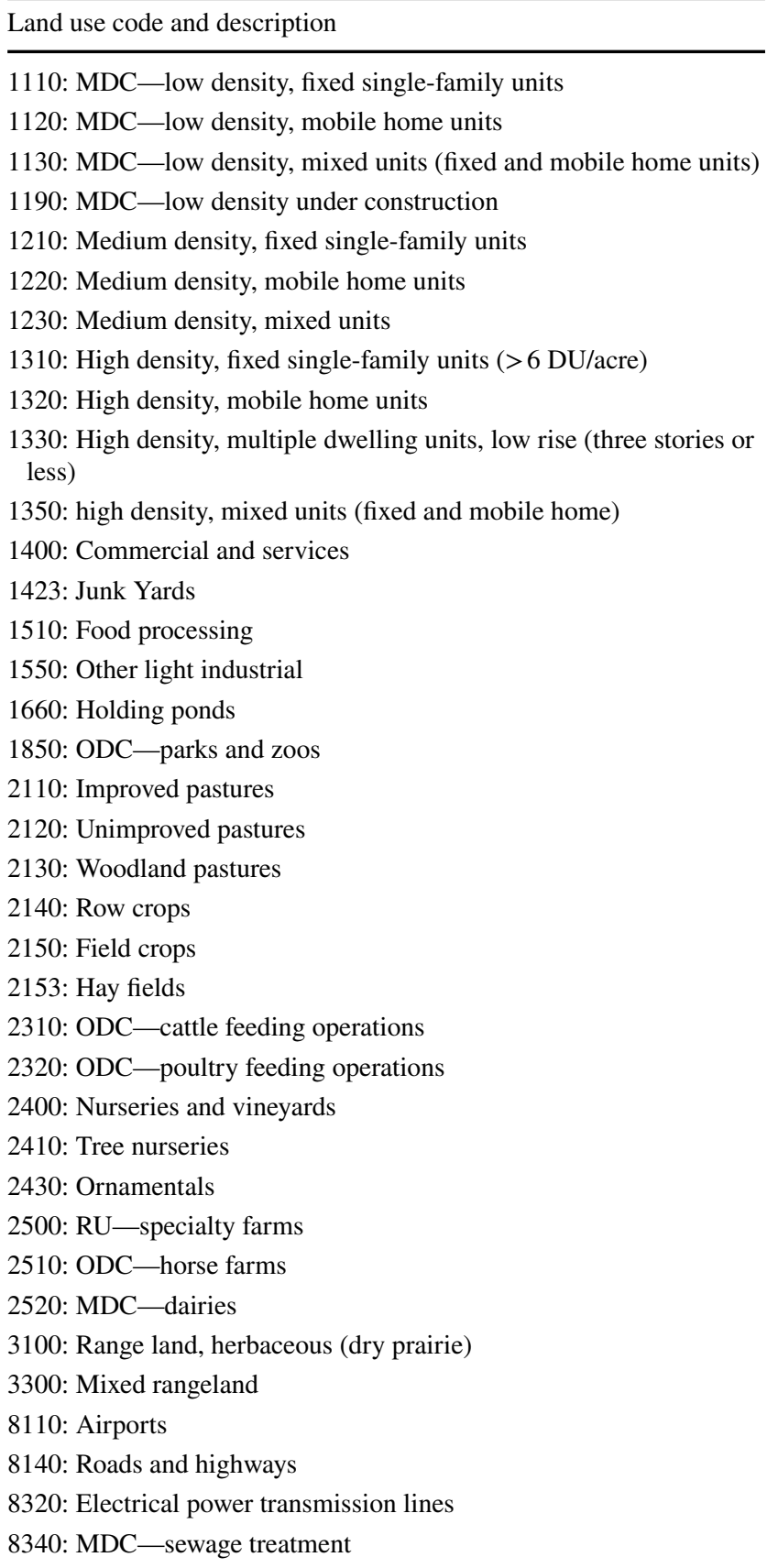

out with the largest increase in residential areas, whereas pasture lands have grown especially around Devil's Ear (6.6\%), Peacock (4.3\%), and Bonnet (4\%) between 2004 and 2013-2014.

In Florida, application of inorganic fertilizers to agricultural lands such as row and field crops, and hay provide the most substantial input to groundwater (Harrington
Table 2 Total areal changes in potentially nutrient-loading land use categories

\begin{tabular}{|c|c|c|c|}
\hline Cave & 2004 & 2013-2014 & Difference \\
\hline Alachua & 58.7 & 50.0 & -8.7 \\
\hline Blue Hole & 47.4 & 47.1 & -0.3 \\
\hline Blue Jackson & 44.3 & 40.5 & -3.8 \\
\hline Bonnet & 41.5 & 47.5 & 6.0 \\
\hline Cathedral-Falmouth & 37.5 & 40.6 & 3.1 \\
\hline Convict & 40.1 & 49.1 & 9.0 \\
\hline Devil's Ear & 28.9 & 39.2 & 10.3 \\
\hline Ginnie & 38.2 & 37.6 & -0.6 \\
\hline Green & 31.8 & 36.8 & 5.0 \\
\hline Hart & 47.3 & 48.7 & 1.4 \\
\hline Indian & 25.2 & 24.1 & -1.1 \\
\hline Leon & 20.1 & 19.9 & -0.2 \\
\hline Little River & 35.0 & 37.5 & 2.5 \\
\hline Luraville & 38.4 & 44.3 & 5.9 \\
\hline Madison Blue & 37.8 & 42.3 & 4.5 \\
\hline Manatee & 24.3 & 22.7 & -1.6 \\
\hline McBride & 24.8 & 24.8 & 0.0 \\
\hline Morgan & 31.9 & 37.1 & 5.2 \\
\hline Peacock & 42.7 & 48.0 & 5.3 \\
\hline Rock Bluff & 35.5 & 36.8 & 1.3 \\
\hline Sally & 26.6 & 26.5 & -0.1 \\
\hline Shepard & 16.2 & 15.6 & -0.6 \\
\hline Suwanacoochee & 31.1 & 37.5 & 6.4 \\
\hline Telford & 37.7 & 43.9 & 6.2 \\
\hline Vortex & 23.9 & 22.0 & -1.9 \\
\hline Wakulla & 25.7 & 25.0 & -0.7 \\
\hline
\end{tabular}

et al. 2010). This study shows that agricultural lands have increased significantly around Suwanacoochee (6.7\%) and Rock Bluff (4.4\%) (Table 3). Moreover, 18 of the 26 caves show increasing rangeland areas within their $10-\mathrm{km}$ buffers. Bonnet, Green, Peacock, Luraville, and Telford springs are among the largest increases in rangeland percentages.

Overall, Cathedral-Falmouth, Devil's Ear, Madison Blue, and Suwanacoochee show increased areal coverage in all of the four nutrient-loading land use categories: residential, pasture, rangeland, and agriculture (crop).

Other important potential nitrogen load sources such as golf courses, poultry and cattle feeding operations, and wastewater treatment plants are also compared. Table 4 lists the number of these sources around each cave. The numbers, instead of areal percentages, of the sources are listed as they do not cover substantial areas, but contribute significantly to the overall nitrogen load. It is alarming to note that the number of sewage treatment plants has increased dramatically 


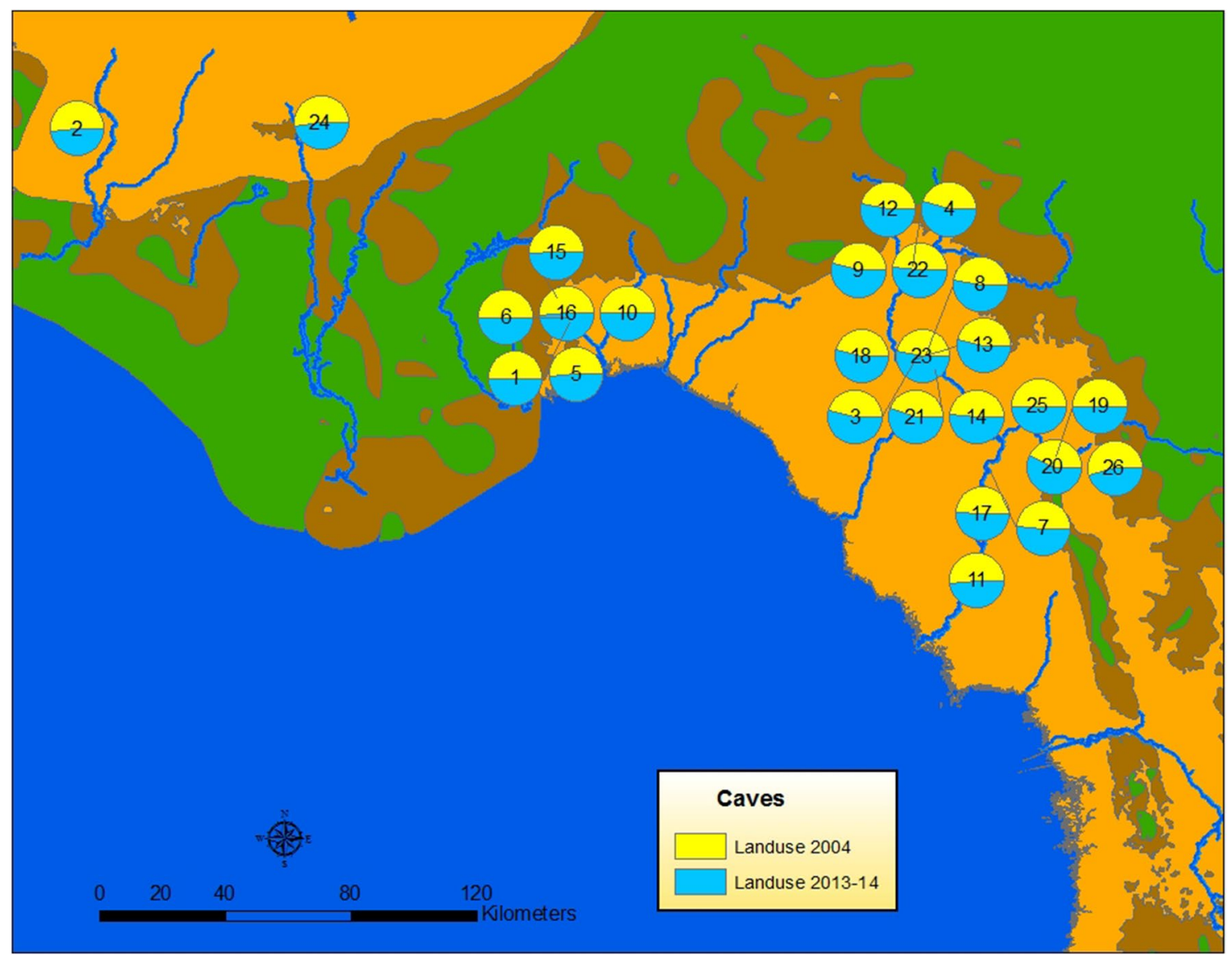

Fig. 7 Nitrate-producing land use changes around caves/springs (1: Wakulla, 2: Vortex, 3: Telford, 4: Suwanacoochee, 5: Shepard; 6: Sally's Ward, 7: Rock Bluff; 8: Peacock, 9: Morgan, 10: McBride, 11: Manatee, 12: Madison Blue, 13: Luraville, 14: Little River, 15: Leon;

within only $10 \mathrm{~km}$ of all but two caves. These domestic wastewater plants account for significant nitrate loads to groundwater (Chelette et al. 2002; Harrington et al. 2010).

Especially where the Floridan aquifer is unconfined or semiconfined, septic tanks, with their lower attenuation factors than other sources, provide potentially more nitrogen input to the Floridan aquifer. Due to the increased development around the cave-spring systems, the number and density of septic systems have also multiplied, significantly degrading the groundwater quality. The percentage of areas with septic systems around the caves calculated in this study are alarming (Table 5 and Fig. 9).

In addition to potentially harmful land use practices, spatial distribution of point contamination sources such as hazardous waste sites should be considered in assessing vulnerability of cave-spring systems to environmental stress.
16: Indian, 17: Hart; 18: Green, 19: Ginnie, 20: Devil's Ear, 21: Convict, 22: Cathedral-Falmouth, 23: Bonnet, 24: Blue Jackson, 25: Blue Hole; 26: Alachua)

This was attempted by a spatial join operation performed in GIS, revealing the number of closest Department of Environmental Protection (DEP) cleanup sites closest to each cave (Table 6 and Fig. 10). Leon cave system with an astonishing number of 206 cleanup sites stands out as the most vulnerable cave system in the study area.

Not only the type of contamination source and the contaminant characteristics, but also the recharge type and the groundwater flow prove to be critical for the Floridan aquifer groundwater quality. Many river and stream sites with significant declining nitrate trends are located where the Floridan aquifer is confined, whereas springs, located on the unconfined area around middle and lower Suwannee River, show increasing nitrate trends (Upchurch et al. 2007). This can be explained by the lack of efficient attenuation of nitrates as recharge occurs through a thin sandy soil cover 


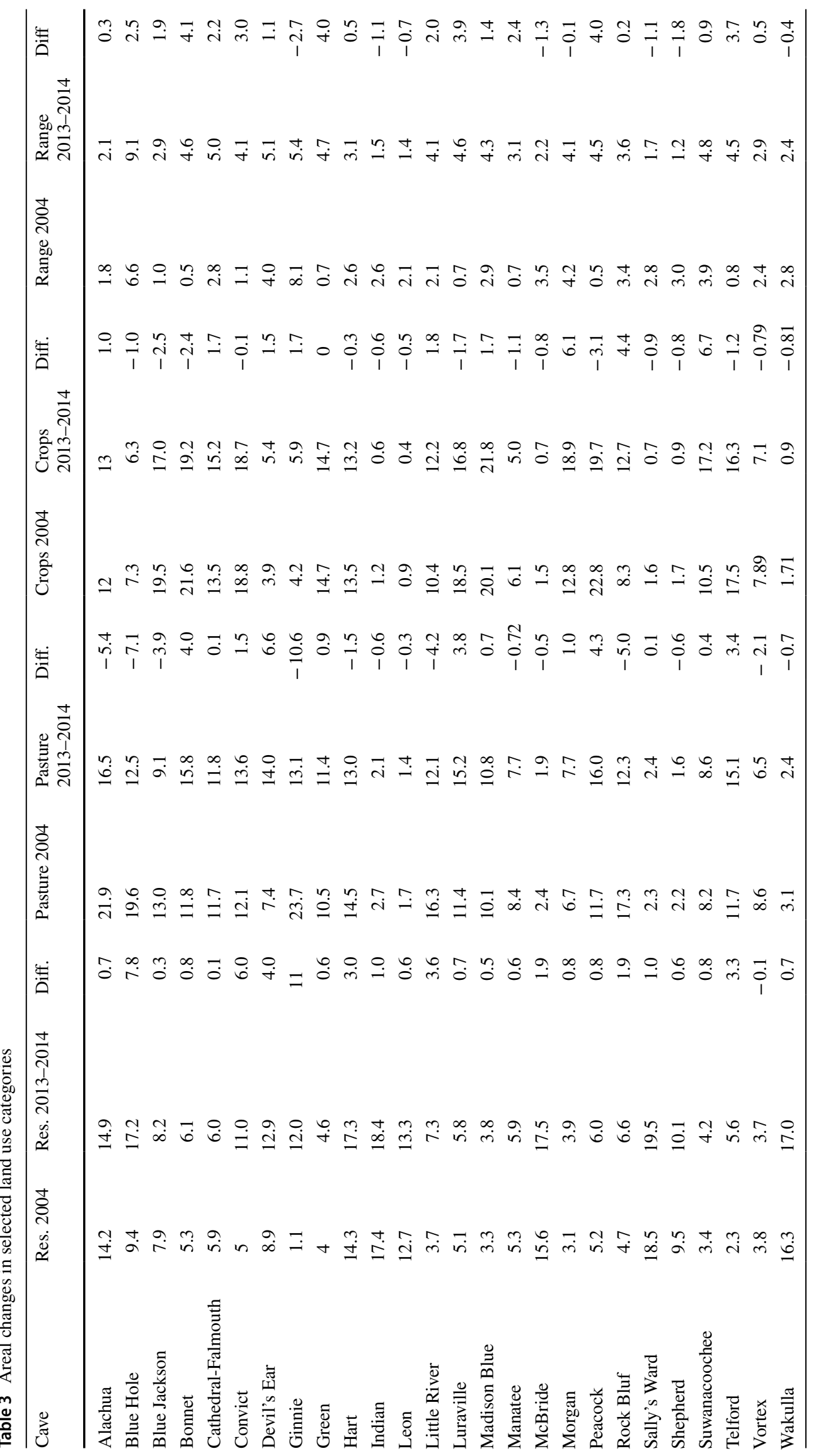




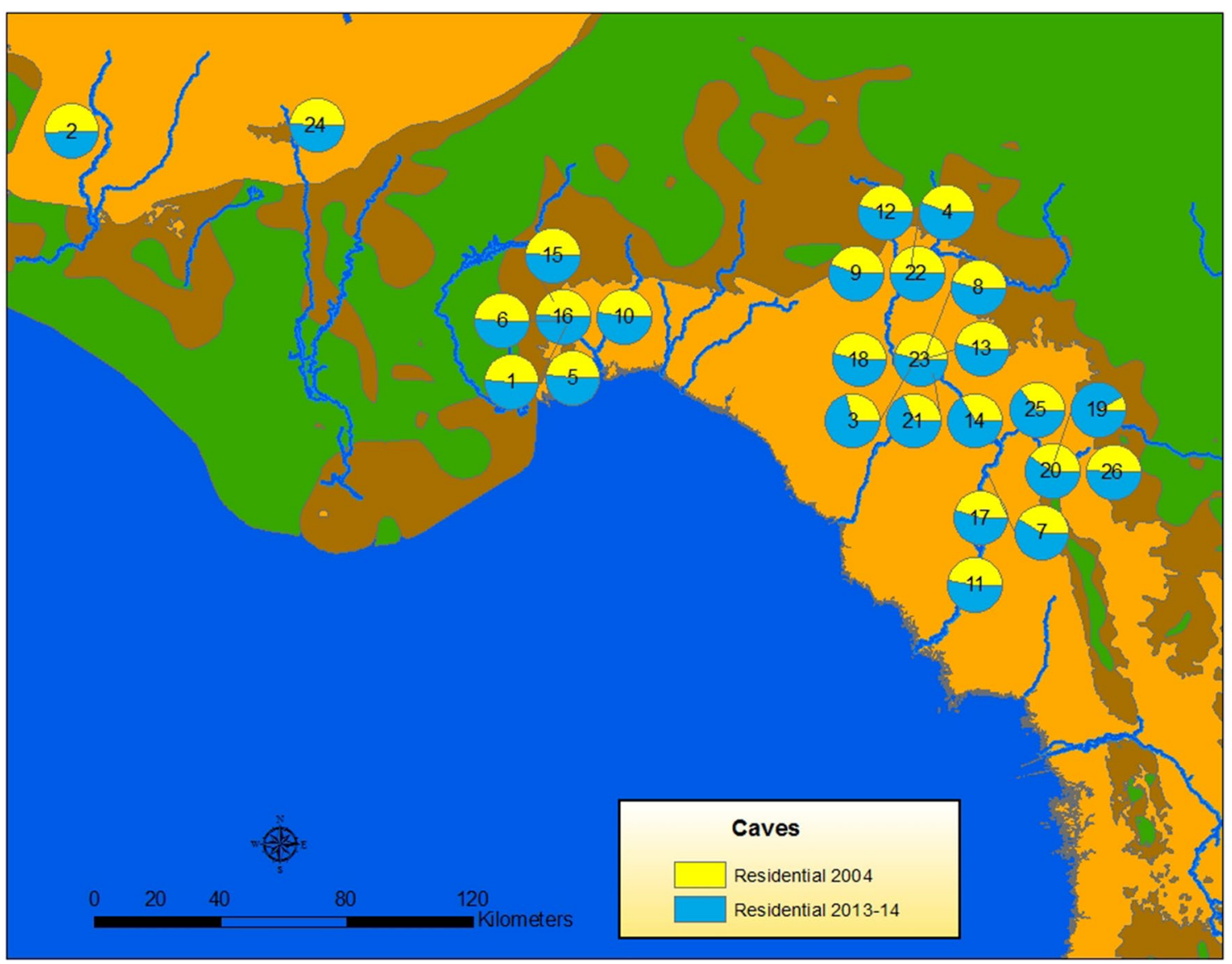

Fig. 8 Residential land use changes around caves/springs

material, concentrating into the epikarstic solution pipes before reaching the Floridan aquifer. On the other hand, contamination may also be critical and rapidly progressing when allogenic streams disappear within the swallets formed along the boundary between unconfined and confined areas.

Dual porosity and associated flow regimes in the Floridan aquifer are revealed by studies on the isotopic age of groundwater and by those that involve dye tracing experiments. Based on the groundwater age information, Katz et al. (2014) state that elevated nitrate concentration will persist in groundwater for decades even after substantial decreases in fertilizer $N$-input. As such, immediate improvements in water quality are not expected, which is typical of Darcian flow conditions that occur within the intergranular (matrix) porosity of the Floridan aquifer. On the other hand, having performed a series of fluorescent dye tracing experiments, Kincaid et al. (2012) report much higher conduit flow velocities (677 to $971 \mathrm{ft} /$ day) between the City of Tallahassee's wastewater spray field and Wakulla Springs.

In karst aquifers, groundwater quality is also affected by the hydraulic balance between the groundwater table and surface runoff, controlling the rate and extent of surface runoff recharge. Karst features may operate as springs or swallets depending on the hydraulic balance. As explained 
Table 4 Number of selected land use categories

\begin{tabular}{|c|c|c|c|c|c|c|c|c|}
\hline \multirow[t]{2}{*}{ Name } & \multicolumn{2}{|c|}{ Golf courses } & \multicolumn{2}{|c|}{ Poultry feeding } & \multicolumn{2}{|c|}{ Cattle feeding } & \multicolumn{2}{|c|}{ Sewage treatment } \\
\hline & 2013 & 2013-2014 & 2013 & 2013-2014 & 2013 & 2013-2014 & 2013 & 2013-2014 \\
\hline Alachua & 3 & 3 & 1 & 0 & 1 & 0 & 4 & 6 \\
\hline Blue Hole & 1 & 1 & 2 & 3 & 1 & 0 & 0 & 2 \\
\hline Blue Jackson & 2 & 2 & 0 & 0 & 1 & 3 & 2 & 3 \\
\hline Bonnet & 0 & 0 & 40 & 35 & 16 & 4 & 2 & 3 \\
\hline Cathedral-Falmouth & 0 & 0 & 43 & 28 & 2 & 1 & 2 & 6 \\
\hline Convict & 0 & 0 & 35 & 32 & 19 & 9 & 2 & 3 \\
\hline Devil's Ear & 0 & 0 & 2 & 1 & 0 & 0 & 0 & 6 \\
\hline Ginnie & 0 & 0 & 2 & 1 & 0 & 0 & 0 & 3 \\
\hline Green & 0 & 0 & 38 & 30 & 14 & 3 & 2 & 5 \\
\hline Hart & 0 & 0 & 0 & 0 & 0 & 1 & 0 & 5 \\
\hline Indian & 0 & 0 & 0 & 0 & 0 & 0 & 0 & 2 \\
\hline Leon & 0 & 0 & 0 & 0 & 0 & 0 & 7 & 5 \\
\hline Little River & 0 & 0 & 12 & 16 & 17 & 3 & 1 & 4 \\
\hline Luraville & 0 & 0 & 45 & 39 & 15 & 4 & 2 & 3 \\
\hline Madison Blue & 0 & 0 & 27 & 10 & 1 & 0 & 0 & 0 \\
\hline Manatee & 1 & 1 & 1 & 0 & 4 & 4 & 1 & 2 \\
\hline McBride & 0 & 0 & 25 & 11 & 2 & 1 & 3 & 5 \\
\hline Morgan & 0 & 0 & 25 & 11 & 2 & 1 & 3 & 5 \\
\hline Peacock & 0 & 0 & 46 & 38 & 14 & 4 & 2 & 3 \\
\hline Rock Bluff & 0 & 0 & 5 & 2 & 1 & 1 & 0 & 0 \\
\hline Sally & 0 & 0 & 0 & 0 & 0 & 0 & 3 & 4 \\
\hline Shepard & 1 & 2 & 0 & 0 & 0 & 0 & 2 & 4 \\
\hline Suwanacoochee & 0 & 0 & 20 & 11 & 1 & 1 & 3 & 5 \\
\hline Telford & 0 & 0 & 37 & 35 & 16 & 4 & 2 & 3 \\
\hline Vortex & 0 & 0 & 29 & 7 & 2 & 1 & 0 & 4 \\
\hline Wakulla & 1 & 2 & 0 & 0 & 0 & 0 & 3 & 5 \\
\hline
\end{tabular}

by Hensley and Cohen (2017), these episodic flow reversals play an important role in regulating the ecosystem state in Florida.

Protective measures have been taken to reduce particularly the agricultural nitrate input by promoting best management practices (BMP). Adopted by many commercial farms, the effectiveness of BMPs is still a topic of discussion (Currens 2002; Prasad and Hochmuth 2016).

\section{Conclusions}

The assessment of land use changes around selected cave-spring systems confirms the existence of anthropogenic impact on the widely reported elevated nitrate concentrations in spring and surface waters of Florida. The water quality of the Floridan aquifer is under severe risk of impairment due to the substantial proliferation of nitrogenproducing land use practices around selected cave/spring 
Table 5 Percentages of septic systems

\begin{tabular}{ll}
\hline Name & Septic area (\%) \\
\hline Alachua & 40.3 \\
Blue Hole & 36.3 \\
Blue Jackson & 28.5 \\
Bonnet & 30.4 \\
Cathedral-Falmouth & 27.0 \\
Convict & 27.3 \\
Devil's Ear & 35.8 \\
Ginnie & 34.8 \\
Green & 29.7 \\
Hart & 34.8 \\
Indian & 32.6 \\
Leon & 27.8 \\
Little River & 24.4 \\
Luraville & 30.5 \\
Madison Blue & 25.6 \\
Manatee & 19.3 \\
McBride & 31.4 \\
Morgan & 21.0 \\
Peacock & 30.0 \\
Rock Bluff & 32.6 \\
Sally & 34.5 \\
Shepard & 19.1 \\
Suwanacoochee & 22.8 \\
Telford & 30.1 \\
Vortex & 26.5 \\
Wakulla & 32.1 \\
\hline
\end{tabular}

system, and significant number of hazardous waste sites in the area. This problem requires improvement on on-site disposal system technologies, continued long-term monitoring of stream and spring flow and quality, and, despite its varying degrees of success, implementation of BMPs, with particular emphasis on nitrogen-fixing agricultural practices.

This study also shows the importance of spatial databases on karst features that are compatible to GIS analyses.
Table 6 Cave/spring systems and the number of closest DEP cleanup sites

\begin{tabular}{lc}
\hline Cave & Number of \\
& DEP sites \\
\hline Alachua & 67 \\
Blue Hole & 43 \\
Blue Jackson & 0 \\
Bonnet & 0 \\
Cathedral-Falmouth & 32 \\
Convict & 1 \\
Devil's Ear & 9 \\
Ginnie & 0 \\
Green & 0 \\
Hart & 9 \\
Indian & 0 \\
Leon & 209 \\
Little River & 3 \\
Luraville & 1 \\
Madison Blue & 24 \\
Manatee & 7 \\
McBride & 24 \\
Morgan & 2 \\
Peacock & 0 \\
Rock Bluff & 0 \\
Sally & 13 \\
Shepard & 0 \\
Suwanacoochee & 1 \\
Telford & 0 \\
Vortex & 10 \\
Wakulla & 0 \\
& \\
&
\end{tabular}

In karst areas, not only common spatial data layers such as hydrology and land use/land cover, but also detailed inventories of karstic features such as caves and depressions are critical in environmental assessments and modeling studies. 


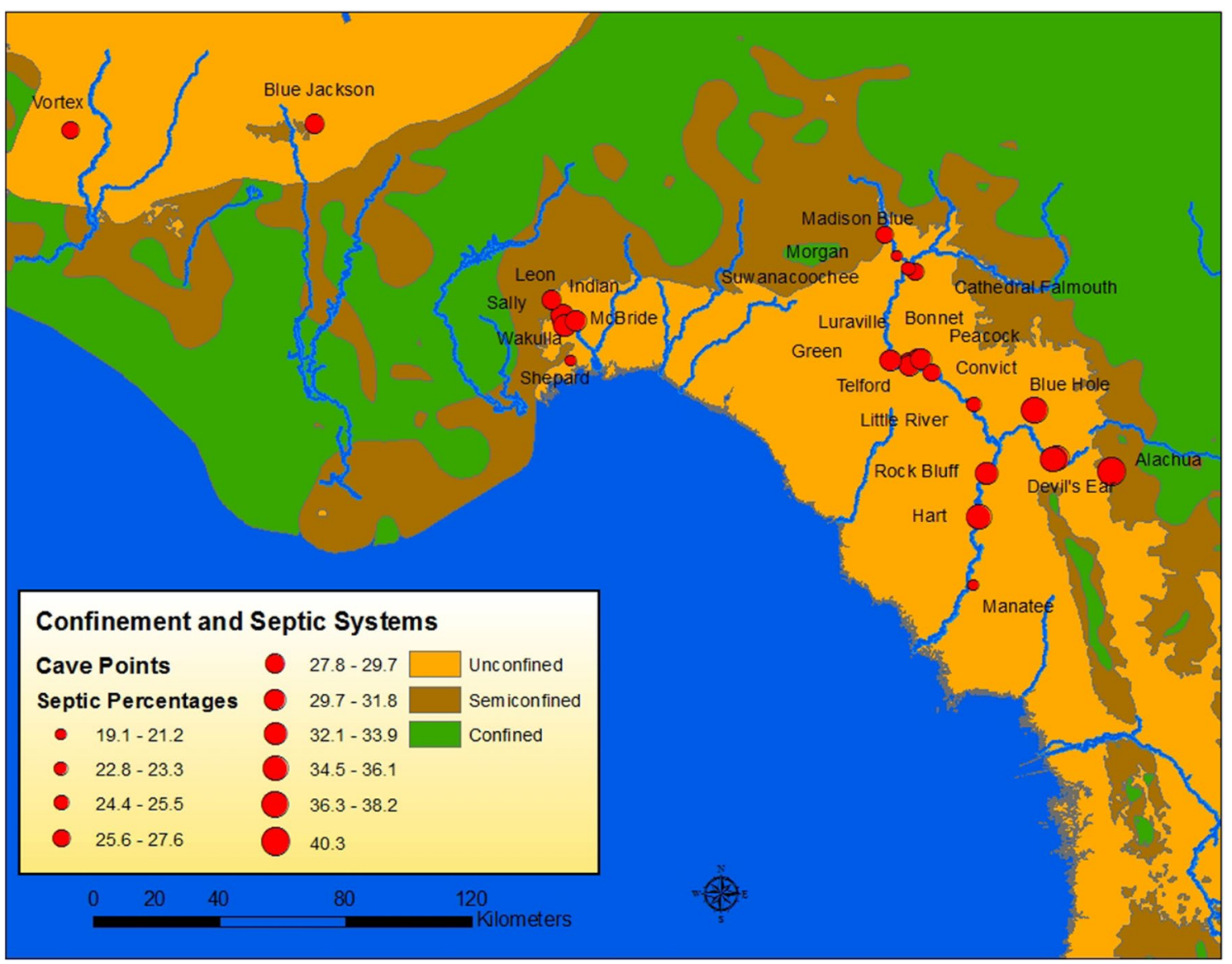

Fig. 9 Percentage of septic systems around caves/springs 


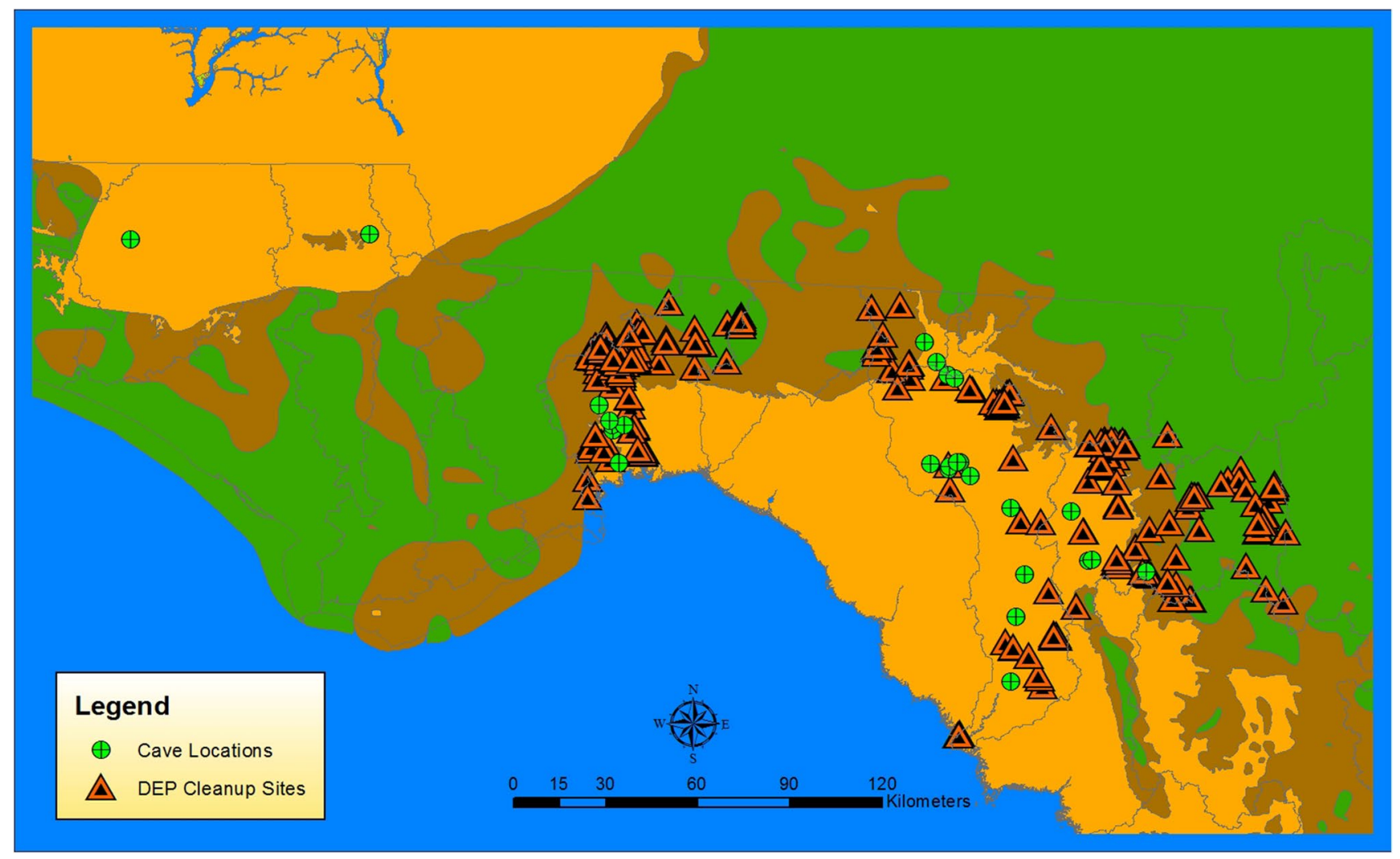

Fig. 10 DEP cleanup sites

\section{Compliance with ethical standards}

Conflict of interest The author declares that there is no conflict of interest.

Open Access This article is distributed under the terms of the Creative Commons Attribution 4.0 International License (http://creativeco mmons.org/licenses/by/4.0/), which permits unrestricted use, distribution, and reproduction in any medium, provided you give appropriate credit to the original author(s) and the source, provide a link to the Creative Commons license, and indicate if changes were made.

\section{References}

Arthur JD, Baker AE, Clichon JR, Wood AR, Rudin A. (2005) Florida Aquifer Vulnerability Assessment (FAVA): contamination potential of Florida's principal aquifer systems, A report submitted to the Division of Water Resource Management, Florida Department of Environmental Protection, Florida Geological Survey, p 148

Barroso MF, Ramalhosa MJ, Olhero A, Antao MC, Pina MF, Guimaraes L, Teixeira J, Afonso MJ, Delerue-Matos C, Chamine HI (2015) Assessment of groundwater contamination in an agricultural peri-urban area (NW Portugal): an integrated approach. Environ Earth Sci 73:2881-2894

Boyer DG (2005) Water quality improvement program effectiveness for carbonate aquifers in grazed land watersheds. J Am Water Resour Assoc 41(2):291-300
Boyer DG, Pasquarell GC (1999) Agricultural land use impacts on bacterial water quality in a karst groundwater aquifer. J Am Water Resour Assoc 36(2):291-300

Bozdag A (2015) Combining AHP with GIS for assessment of irrigation water quality in Cumra irrigation district (Konya), Central Anatolia, Turkey. Environ Earth Sci 73:8217-8236

Capri E, Civita M, Corniello A, Cusimano G, De Maio M, Ducci D, Fait G, Fiorucci A, Hauser S, Pisciotta A, Pranzini G, Trevisan M, Huertas AD, Ferrari F, Frullini R, Nisi B, Offi M, Vaselli O, Vasallo M (2009) Assessment of nitrate contamination risk: the Italian experience. J Geochem Explor 102:71-86

Champion KM, DeWitt DJ (2000) Origin of nitrate in groundwater discharging from Crystal Springs, Pasco County, Florida: Brooksville. Southwest Florida Water Management District Report, p 191

Chelette A, Pratt TR, Katz BG (2002) Nitrate loading as an indicator of nonpoint source pollution in the Lower St. Marks-Wakulla Rivers watershed. Northwest Florida Water Management District, Water Resources Special Report 02-1. p 138

Copeland R, Doran NA, White AJ, Upchurch, SB (2011) Regional and statewide trends in Florida's spring and well groundwater quality (1991-2003). Florida Geological Survey, Bulletin No. 69 (Revised), p 393

COST Action 620 (2004) Vulnerability and risk mapping for the protection of carbonate (karst) aquifers, Final Report (COST Action 620), Report EUR 20912, Directorate-General Science, Research and Development, European Commission, Office for Official Publications of the European Communities, Luxembourg, p 297

Currens JC (2002) Changes in groundwater quality in a conduit-flowdominated karst aquifer following BMP implementation. Environ Geol 42:525-531 
Davis AD, Long AJ, Wireman M (2002) KARSTIC: a sensitivity method for carbonate aquifers in karst terrain. Environ Geol 42:65-72

Edet A (2014) An aquifer vulnerability assessment of the Benin Formation aquifer, Calabar, southeastern Nigeria, using DRASTIC and GIS approach. Environ Earth Sci 71:1747-1765

Edwards TM, Miller HD, Guillette Jr. LJ (2006) Water quality influences reproduction in female mosquitofish (Gambusia holbrooki) from eight Florida springs. Environ Health Perspect 114 (suppl 1):69-75

Eftimi R, Zojer H (2015) Human impacts on karst aquifers of Albania. Environ Earth Sci 74:57-70

Elisante E, Muzuka ANN (2017) Occurrence of nitrate in Tanzanian groundwater aquifers: a review. Appl Water Sci 7:71-87

Eller KT, Katz BG (2014) Nitrogen source inventory and loading estimates for the Wakulla spring BMAP contributing area. Florida Department of Environmental Protection, Tallahassee, p 56

Fulton RS III, Godwin WF, Schaus MH (2014) Water quality changes following nutrient loading reduction and biomanipulation in a large shallow subtropical lake, Lake Griffin, Florida, USA. Hydrobiologia 753:243-263

Gao Y, Zhou W (2008) Advances and challenges of GIS and DBMS applications in karst. Environ Geol 54:901-904

Guo F, Jiang G, Yuan D (2006) Major ions in typical subterranean rivers and their anthropogenic impacts in southwest karst areas, China. Environ Geol 53:533-541

Harrington D, Maddox G, Hicks PG (2010) Florida springs initiative monitoring network and recognized sources of nitrate. Florida Department of Environmental Protection, Division of Environmental Assessment and Restoration, Bureau of Watershed Restoration, Groundwater Protection Section, $\mathrm{p} 102$

Hartmann A, Goldscheider N, Wagener T, Lange J, Weiler M (2014) Karst water resources in a changing world: review of hyrological modelling approaches. Rev Geophys 52:218-242

Hasenmuller NR, Buehler MA, Krothe NC, Comer JB, Branam TD, Ennis MV, Smith RT, Zamani DD, Hahn L, Rybarczyk JP, Harmon RS, Wicks CM (2006) Water-quality characteristics and contaminants in the rural karst-dominated Spring Mill Lake watershed, southern Indiana. Perspectives on karst geomorphology, hydrology, and geochemistry. The Geological Society of America Special Paper, Boulder, pp 153-167

Heffernon TM, Liebowitz DM, Frazer TK, Evans JM, Matthew JC (2010) Algal blooms and the nitrogen-enrichment hypothesis in Florida springs: evidence, alternatives, and adaptive management. Ecol Appl 20(3):816-829

Hensley RT, Cohen MJ (2017) Flow rehearsals as a driver of ecosystem transition in Florida's springs. Freshw Sci 36(1):14

Hornsby D, Ceryak R, Zwanka W (2004) Groundwater quality \& biological annual report, Suwannee River Water Management District, Live Oak, Florida, WR-04/05-05, p 48

Jasrotia AS, Kumar A (2014) Groundwater quality mapping based on the geographical information system (GIS) of Jammu District, Jammu and Kashmir India. J Spat Hydrol 12(1):1-21

Jiang Y, Yan J (2010) Effects of land use on hydrochemistry and contamination of Karst groundwater from Nandong underground river system, China. Water Air Soil Pollut 210:123-141

Jimenez-Madrid A, Carrasco-Cantos F, Martines-Navarrete C (2012) Protection of groundwater intended for human consumption: a proposed methodology for defining safeguard zones. Environ Earth Sci 65:2391-2406

Jones GW, Upchurch SB, Champion KM (1996) Origin of nitrate in groundwater discharging from rainbow springs, Marion County, Florida: Brooksville, Southwest Florida Water Management District Report, p 155

Katz BG, Berndt MP, Crandall CA (2014) Factors affecting the movement and persistence of nitrate and pesticides in the surficial and upper Floridan aquifers in two agricultural areas in the southeastern United States. Environ Earth Sci 71:2779-2795

Khan HH, Khan A, Ahmed S, Perrin J (2011) GIS-based impact assessment of land-use changes on groundwater quality: study from a rapidly urbanizing region of South India. Environ Earth Sci 63:1289-1302

Khan A, Khan HH, Umar R (2017) Impact of land-use on groundwater quality: GIS-based study from an alluvial aquifer in the Western Ganges basin. Appl Water Sci 7:4593-4603

Ki M, Koh D, Yoon H, Kim H (2015) Temporal variability of nitrate concentration in groundwater affected by intensive agricultural activities in a rural area of Hongseong, South Korea. Environ Earth Sci 74:6147-6161

Kihumbal AM, Longo JN, Vanclooster M (2016) Modelling nitrate pollution pressure using a multivariate statistical approach: the case of Kinshasa groundwater body, Democratic Republic of Congo. Hydrogeol J 24:425-437

Kincaid T, Davies G, Werner C, DeHan R (2012) Demonstrating interconnection between a wastewater application facility and a first magnitude spring in a karstic watershed: tracer study of the Tallahassee, Florida Treated Effluent Spray Field, 20062007. Florida Geological Survey Report of Investigation No. $111, \mathrm{p} 192$

Lan F, Qin X, Jiang Z, Meng R, Mo R, Yang S, Wang W, An S (2015) Influences of land use/land cover on hydrogeochemical indexes of Karst groundwater in the Dagouhe Basin, Southwest China. CSAWAC 43(5):621-786

Lapointe BE, Herren LW, Deportoli DD, Vogel RA (2015) Evidence of sewage-driven eutrophication and harmful algal blooms in Florida's Indian River Lagoon

Miller JA (1986) Hydrogeologic framework of the Floridan aquifer system in Florida and parts of Georgia, Alabama, and South Carolina. U. S. Geological Survey Professional Paper no. 1403-B. p 91

Miller JA (1997) Hydrogeology of Florida. In: Randazzo AF, Smith DS (eds) The geology of Florida. University Press of Florida, Gainesville, pp 57-68

Plagnes V, Bakalowicz M (2001) The protection of karst water resources: the example of the Larzac karst plateau (south of France). Environ Geol 40(3):349-358

Prasad R, Hochmuth JG (2016) Environmental nitrogen losses from commercial crop production systems in the Suwannee River Basin of Florida. PLoS ONE 11(12):e017558. https://doi.org/10.1371/ journal.pone:0167588

Quinlan JF (1983) Groundwater pollution by sewage, creamery waste heavy metals in the Horse Cave area. Kentucky. In: Dougherty PH (ed) Environmental Karst. Geology and Speleology Publications, Cincinnati, p 52

Stark SL, Nuckols JR, Rada J (1999) Using GIS to investigate septic system sites and nitrate pollution potential. J Environ Health 61(8):15-20

Sener E, Davraz A (2013) Assessment of groundwater vulnerability based on a modified DRASTIC model, GIS and an analytic hierarchy process (AHP) method: the case of Egirdir Lake basin (Isparta, Turkey). Hydrogeol J 21:701-714

Tokatli C (2014) Drinking water quality of a rice land in Turkey by statistical and GIS perspectives. Pol J Environ Stud 23(6):2247-2258

Upchurch SB, Lawrence FW (1984) Impact of ground-water chemistry on sinkhole development along a retreating scarp. In: Beck BF (ed) Sinkholes: their geology, engineering \& environmental impact. A.A. Balkema, Rotterdam, pp 23-28

Upchurch SB, Chen J, Cain CR (2007) Trends of nitrate concentrations in waters of the Suwannee River Water Management District, 2007. SDII Global Corporation Project Number: 3017076 , p.36

Vallejos A, Andreu JM, Sola F, Pulid-Bosch A (2015) The anthropogenic impacts on Mediterranean karst aquifers: cases of some Spanish aquifers. Environ Earth Sci 74:185-189 
Williams LJ, Kuniansky EL (2016). Revised hydrogeologic framework of the Floridan aquifer system in Florida and parts of Georgia, Alabama, and South Carolina. In: USGS professional paper 1807 Version 1.1, p 140

Wongsabit J, Teartisup P, Kerdsue P, Thatnpoohasiam P, Wroakhunpiset $S$ (2015) Contamination of nitrate in groundwater and its potential human health: a case study of lower Mae Klong river basin, Thailand. Environ Sci Pollut Res 22:11504-11512

Worthington SRH, Smart CC, Ruland WW (2002) Assessment of groundwater velocities to the municipal wells at Walkerton. In: Stolle D, Piggot AR, CrowderJJ (eds) Proceedings of the 55th
Canadian geotechnical and 3rd joint IAH-CNC and CGS groundwater specialty conferences, Niagara Falls, Ontario, October 20-23, 2002, Southern Ontario section of the Canadian geotechnical society, pp 1081-1086

Publisher's note Springer Nature remains neutral with regard to jurisdictional claims in published maps and institutional affiliations. 